\title{
Stylistic Analysis of Emily Brontë's Wuthering Heights
}

\author{
Dr. Lata Marina Varghese \\ (Associate Professor, Department of English, Catholicate College, Pathanamthitta, Kerala, INDIA)
}

\begin{abstract}
Few debut novels have aroused as much controversy as Wuthering Heights based on themes, style or on techniques. Although, Wuthering Heights scandalized and nauseated the Victorians, modern critics, nevertheless, speak highly of the strength of the novel's structure and on Emily Brontë's dynamic and disciplined handling of language. A novel comes into existence through the creativity of the writer. And the readers come in contact with the fictional world of the novels through its language. Hence, for comprehending fictional texts, a close study and analysis of language is a necessary prerequisite. Stylistic analysis is used as an analytical tool to see textual patterns and its significance. It is based on statistical data that validate how language, vocabulary and syntax are used to bring about interpretation of the text. Wuthering Heights presents a variety of styles. Stylistically, much ahead of her time, Brontë culled a form best suited to articulate her subject and ideas effectively. This paper is, therefore, an attempt to discover what is striking about Brontë's narrative style.
\end{abstract}

Keywords: Emily Bronte, Wuthering Heights, Stylistic analysis

\section{Introduction}

Few debut novels have aroused as much controversy as Wuthering Heights based on themes, style or on techniques. The fact that Wuthering Heights, on its promulgation had been deemed as 'coarse', 'immoral', and 'unwomanly', in itself testifies that it deserves serious critical deliberation. Wuthering Heights scandalized and nauseated the Victorians. 'Brutal', 'disagreeable' and 'diabolical' have been some of the adjectives lavished on it by the early reviewers. Modern critics, nevertheless, speak highly of the strength of the novel's structure and on Emily Brontë's dynamic and disciplined handling of language. Stylistically, much ahead of her time, Brontë culled a form best suited to articulate her subject and ideas effectively. In fact, Mark Schorer praises Wuthering Heights as, "one of the most carefully constructed novels in the language" (Volger 63).

The novel, as an effective medium for the criticism and interpretation of life, comes into existence through the creativity of the writer. A literary text is an artifice; a work of art. The readers come in contact with the fictional world of the novels through its language. The fictional world of the novel is a 'verbal' world that is determined at every point by the words in which it is represented. Hence, for comprehending fictional texts, a close study and analysis of language is a necessary prerequisite. David Lodge in The Language of Fiction has made this significant statement, "The novelist's medium is language: what he does, qua novelist, he does in and through language" (Preface 1966:1X). The creativity of fiction depends to a large extent on the novelist's artistic manipulation of the resources of language in order to attain certain aesthetic effect. Therefore, to understand a text, both "Literary Competence" (Jonathan Culler) and "Linguistic Competence" (Chomsky), are indispensable criteria. But a reader must not remain content to just "look in language; rather he should look through language" (Leech and Short 38), for analytical techniques of linguistics are very much sine qua non for understanding the aesthetic effect of a literary text. Hence, linguistic observation and literary insight are complementary and necessary for a proper interpretation of a literary text.

Analyzing involves 'tearing apart' a text into its multifarious components to discover the function of each part and in pinpointing how the author 'puts' it all together to create an aesthetic whole. This promotes a deeper understanding and fuller appreciation of the literary text. Northrop Frye (1961) in his essay Myth, Fiction and Displacement, observes "...every word, every image, even every sound made audibly or inaudibly by the words is making tiny contribution to the told movement..."(402 ). An analysis, thus, explains what a work of literature means, since it is essentially an articulation in defence of an author's 'vision' of life. Besides, it shows how resources of language -images, the essential process of meaning-making, are utilized to create works of literature. As a result, the reader acquires greater awareness of recognising and using narrative devices, tools and techniques present in the text. This in turn exerts a profound influence on the reader's response to the imaginative 'world' created by the novelist.

The primary texture of a text is its language. It is through language that the content of a text finds its fullest expression. So, when a text is analyzed, its linguistic features are of prime importance. One of the most obvious features of a writer's individual style is his fondness for certain words or types of words, which provides a clue to the predominant attitude of the writer. Besides, lexis is perhaps, that level of linguistic form at which variables can be treated with the greatest freedom and hence are of greater significance in the study of 
language. The vocabulary consists of lexical words and grammatical words, of which the lexical words refer to what is being interpersonally expressed; grammatical words provide the syntactic framework of a sentence. Similarly, stylistic analysis of sentence structures is a necessary foundation for understanding a text. Although the grammar of a language is represented by its conventional structuring, difference in the kinds of sentence patterns reflects different attitudes to experience. A study of the patterns of syntactic prominence helps in revealing the thesis or theme which adds to the meaning of a work. Besides, it also helps to detect and analyse ambiguity. Hence, the role of syntax in language is to weave into a single fabric the different threads of meaning that are derived from the variety of linguistic function. Apart from lexis and syntax, many critics have also stressed the importance of imagery in literature, for it is a concrete representation of sense impression, a feeling or an idea that appeals to one or more of the human senses. Hence, imagery or figurative language, as a structuring device, is of prime importance in a novel as it helps in learning about local effects.

It is the craft and veracity of narrative patterns present in Emily Brontë's Wuthering Heights that has impelled a stylistic analysis of the novel. Stylistic analysis, based on statistical data, is used as an analytical tool in order to discover the textual patterns present in the text and to note its significance. This helps in validating how language, vocabulary and syntax, are used to bring about interpretation of the text. In addition, it also reveals the mechanisms which underlie the work's meaning or style. Although a Victorian novel, the richness and complexity of Wuthering Heights continue to inspire critical interpretations even after more than a hundred years of its publication. This is no doubt a tribute to the creative genius of its author. As a work of art, the novel invites criticism which is mainly stylistic and pertains to image patterns and formal structure.

Wuthering Heights presents a variety of styles ranging from Catherine's poetic discourse, Heathcliff's verbal violence, Lockwood's superior literary tone and fashionable cliché, Nelly's homiletic rhetoric to Joseph's biblical Yorkshire dialect and unintelligible muttering--all producing an interplay of accents and idioms, giving rise to what Bakhtin terms as "dialogical heteroglossia". However, the single most distinctive feature of Wuthering Heights is its dialogue with Brontë's emphasis on personal idiolect. To make this possible she dismantles language in order to make the language of social behaviour in her fictional world intelligible to her readers. Consequently, the diction used by various characters reveals their speech style. But although a skilled craftswoman, Brontë, desists from ornate verbal display. Her linguistic style depends largely on her admirable choice of words, though it is marked by hyperbolic excess especially in the dramatic speeches of Catherine and Heathcliff. The directness of Brontë's style is amply demonstrated in the very opening paragraphs of Chapter one in the novel. This is one of the innumerable examples of the direct method of introducing movement by means of extra accent upon certain focusing words. Each sentence goes straight as a dart to the impression sought to be conveyed (Allot 143):

Pure bracing ventilation they must have up there at all times, indeed one may guess the power of the north wind blowing over the edge, by the excessive slant of a few stunted firs at the end of the house; and by a range of gaunt thorns all stretching their limbs one way, as if craving alms of the sun (2).

The paragraph conveys a vivid impression of the way the wind blows up on the heights. Similarly, Lockwood's entry into the interior of the house is matched exactly with the action it describes. "One step brought us into the family sitting-room, without any introductory lobby or passage" (2).

On closer analysis, one discovers that the most distinctive single trait in Emily Brontë's narrative style is repetition. Everything in the novel is a kind of double. There are not only verbal repetitions, but the plot, structure, narrators, and the characters themselves form a double to each other. There are even two diary accounts, Catherine's diary forming a kind of inner text to Lockwood's diary which forms the outer text. Most of the repeated words in the text are content words (Noun, Verb, Adjective and their derivatives). Words repeated tend to stick longer in the mind. But repetition is confined not only to words or sentences but extends to include even ideas (images) that express the theme(s) of the novel.

At the lexical level, the very texture of language, i.e., vocabulary is examined. Emily Brontë's range of diction is remarkable. Stevie Davies, in fact, elucidates that the copious and literary vocabulary in the novel is founded in a pithy Anglo-Saxon- derived lexis and that the vocabulary is often Latinated and polysyllabic (1998:100-101). One is introduced to Wuthering Heights first through the filter of Lockwood's language. The most distinctive feature in Lockwood's speeches is its 'literariness'. It is stilted, pompous, mannered, 'bookish' and riddled with clichés. Besides, he uses hackneyed and affected language, like in his description of his seaside flirtation with "a most fascinating creature--a real goddess" (3) who was also a "poor innocent". Further, he speaks of Cathy as Heathcliff's "amiable lady", then of Hareton as the "favoured possessor of the beneficent fairy" (9). Taking Cathy to be Hareton's wife, he fantasizes himself to be a possible seducer of Cathy. "She has thrown herself away upon that boor from sheer ignorance that better individuals existed! A sad pity...I must beware how I make her regret her choice" (8). However, Lockwood's narration presents a conflict between the literary genre and the social reality the narrative has moved into; the chasm between his mannered literary language and the domestic reality at the Heights. His speech is often marked by artificiality due to 
circumlocutions, use of Latinism, and fondness for ready-made, bombastic and trite phrases. Lockwood's diction, thus, shows no variation, as it remains the same from the beginning of the novel to the end.

Nelly's language, at times, shows certain similarity with Lockwood's. For instance:

"He entered, vociferating oaths dreadful to hear; and caught me in the act of stowing his son away in the kitchen cupboard" (52).

"As soon as I perused this epistle, I went to the master..." (106).

Lockwood admires Nelly's language because it is compatible with his own. Analysis of their speech patterns show that both Lockwood's and Nelly's dialogues share a certain blandness and fixity. Nelly's narrative style consists of verbatim dialogue. Much of her narrative is unfolded in the words of the actual character. But when she speaks for herself, her language is lively, colloquial, and imaginative by the use of many vivid and precise images, like in her reference to Heathcliff's history, "It's a cuckoo's, sir - I know all about it, except where he was born, and who were his parents, and how he got his money at first. And that Hareton " has been cast out like a unfledged dunnock" (24). Thus, one finds that Nelly possessess two styles -her style while talking to Lockwood is indistinguishable from contemporary narrative prose and her own narrative with its emphatic speech rhythm and plain language shows almost no variation.

An investigation of Heathcliff's speech reveals that his diction shows considerable variation. His style has a certain development throughout the novel. His first words as a child are described as "gibberish that nobody could understand" (25), and before he articulates his last words; there are many modulations in between. As a boy, when he is caught trespassing at the Grange, he lets out a volley of curses which shock his listeners and make Mrs. Linton exclaims, "Did you notice his language?"(35)[emphasis mine].On Heathcliff's return from his wanderings, Nelly describes his voice as "foreign in tone". Marsh authenticates that there are two distinct styles in Heathcliff's speeches. So, his speech appears rough and violent when compared with Lockwood's and Nelly's. Likewise, he also parodies and satirizes others' speech especially that of Edgar and Isabella, whose speech he treats with equal sarcasm and with utters contempt (1999:21-22).

In contrast, when he talks to Nelly about Catherine or when he talks to Catherine, especially when she is on her death bed, it is emotionally charged. Almost always rough and violent, his vocabulary consists of short words and simple physical verbs. For example:

"Thrushcross Grange is my own, sir', he interrupted, wincing. "I should not allow anyone to inconvenience me, if I could hinder it--Walk in!"(1).

"Oh, God confound you, Mr. Lockwood! I wish you were at the--"(18).

"Come in! come in!" he sobbed. "Cathy, do come. Oh do-once more!"(20).

Heathcliff's language reveals his nature. His diction expresses violence and harshness. The only occasion where he is found to soften, become more human-like, is when he breaks down and weeps for Catherine's ghost to 'come in'. Heathcliff's contempt for Edgar is made quite clear in these sentences: "Cathy, this lamb of yours [Edgar] threatens like a bull" he said. "It is in danger of splitting its skull against my knuckles" (83). Heathcliff's diction clearly reveals his propensity in using strong words to express his feelings. As a self-made man, though almost illiterate, he later manages to speak and behave in a polished and refined manner. So, there is nothing in the actual spelling or grammar of the dialogue to suggest any difference between Heathcliff's speech and that of the other major characters. Brontë by minimizing differences in Heathcliff's language brings him from the margins to the centre of the fictional world. At the same time she places the speeches of all the characters in sharp contrast with Joseph's dialect so as to root the story firmly in its locale.

Catherine's diction too is not fixed either, though her tone is often imperious. One first hears of her through her diary which Lockwood reads: "An awful Sunday!...H and I are going to rebel...we took our initiatory step this evening" (13), to the ghostly voice in Lockwood's dream "Let me in! Let me in!. I'm come home: I'd lost my way on the moor!'(17). Her confessions made to Nelly are considered as one of the most dramatic speeches in the novel, especially when she says, "I am Heathcliff!"(59). So also when she describes her love for Heathcliff which she says is different from what she feels for Edgar. Her diction vacillates from child-like utterance to passionate outburst.

Hareton's diction shows a development but one stops hearing his voice as the book ends. Cathy's and Linton's diction reveal them as spoiled children. Joseph's diction shows no variation. Like Lockwood's and Nelly's, it remains the same from the beginning to the end of the story. Brontë minimizes language differences, even with its differences, among her central characters by contrasting it with the almost unintelligible speech of Joseph. This helps in making the novel a unified whole. The different voices also help to trace the important divisions among the characters. Heathcliff, when he was brought to the Heights spoke "gibberish that no one could understand". Isabella on being brought to the Heights as Heathcliff's bride cannot comprehend the jargon used by the boy Hareton. Cathy and Linton laugh at young Hareton's pronunciation which they find so strange. 
But most of all it is Joseph's speech with its pronounced Yorkshire accent that is most unintelligible. He, in turn, mocks Isabella's and Lockwood's polite literary speech.

One of the most prominent features of Emily Brontë's style is that it is syntax of excess - of hyperbolic expression, although the syntactic structures contain a lot of variation. Brontë makes use of long sentences as well as short sentences, and even fragmentary syntax. Her long sentences sometimes form a paragraph in itself, and she uses it with great dexterity. Her syntactic construction also contains a lot of paralinguistic devices which she uses with telling effect especially in the dramatic utterance of Catherine and Heathcliff. Most of Heathcliff's sentences incorporate complex situations, so their loose, wandering structure reflects the conflict of feelings and desires. At the same time, it also reveals Heathcliff's inability to articulate his feelings in words. Catherine experiences similar difficulty in articulating her feelings for Heathcliff:
"I cannot express it; but surely you and everybody have a notion that there is or should be an existence of yours beyond you... My great miseries in this world have been Heathcliff's... my great thought in living is himself. If all else perished and he remained, I should still continue to be; and if all else remained, and he were annihilated, the universe would turn to a mighty stranger: I should not seem a part of it. My love for Linton is like the foliage in the woods: time will change it, I'm well aware, as winter changes the trees. My love for Heathcliff resembles the eternal rocks beneath: a source of little visible delight, but necessary. Nelly, I am Heathcliff!" (59).

A stylistic analysis of the text reveals the problems of language that Emily Brontë had to face in writing of the love of Heathcliff and Catherine: the problem of expressing a great tragic passion in nineteenth century prose. But she tackles it and in doing so, proved herself to be far ahead of her time, for not until D.H. Lawrence did another novelist ever attempt to find a language-a prose language-for passion. To lay bare the inner anguish and turmoil of the lovers, Brontë uses various poetic devices, especially strong metaphors through the dialogues, which has created some of the profoundest passages in the novel. Herein lies the strength and charm of her style. Further, her penchant for the Complex-Compound construction is in keeping with the prose style of the Victorian age and also reflects the intricate narrative structure and adds meaning to the central theme. Brontë's long sentence is definitely a statement of her overall thematic and structural considerations.

It is evident that Brontë's art finds its best expression in her imagery. In fact, the entire novel contains a network of images. Brontë creates a compelling illusion of an actual regional world through selective use of striking visual images. On analyzing Brontë's imagery, one finds that the figurative ideas or images add to the literal meaning of the story. One of the most striking imagery in the text occurs at the very beginning of the novel. It is through Lockwood one enters the fictional world of Wuthering Heights as well as the verbal structure of the same name. This is what he says about the landscape around the Heights:

One may guess the power of the north wind blowing over the edge, by the excessive slant of a few stunted firs at the end of the house; and by a range of gaunt thorns all stretching their limbs one way, as if craving alms of the sun (2).

Language in the novel comes alive, becomes even violent and the apparent binary oppositions present in the novel, at all levels, are responsible for the heightened intensity of the novel's language. Evidently, her book gains its extraordinary power from her manipulation of images whose unexpected appearance out of apparent context lends them a symbolic life. In fact, Wuthering Heights seems to be rooted in metaphorical analogies. Brontë's imagery, most of which cluster around Heathcliff, is expressed through her powerful metaphors. "Heathcliff is ... an arid wilderness of furze and whinstone. I'd as soon put that canary into the park on a winter's day as recommend you to bestow your heart to him!'(74). Effects in the novel are continually created through comparative imagery as well as in the use of active verbs and adjectives which like other elements in the novel add to the literal meaning of the story, and help one to understand the book's effect. The sparse but vivid description certainly gives the text a highly emotive texture.

Leech and Short assert that all literary works show signs of being both 'Transparent' and 'Opaque' at the same time (1981:29), although the degree of transparency and opacity varies. A text is considered to be 'TRANSPARENT' when the language used in it does not attract the reader's attention more than the content, i.e. it is not foregrounded. Brontë's novel shows signs of being 'Transparent' for it calls attention more to its content and structure than to its style. There is no apparent violation of the rules of language in the novel and neither does it confront the readers with unexpected linguistic forms in terms of frequency norms. At the same time, there is no doubt that Brontë's strength lie in her diction, sentence construction and use of powerful imagery. All these have helped Brontë forge her own unique, distinct and idiosyncratic style. Wuthering Heights 
exhibit great craftsmanship. Brontë's originality, thus, lies in her stylistic control over her linguistic resource, her diction and image pattern, for she employs both language and narrative technique to establish a structural pattern.

\section{Conclusion}

To sum up, Wuthering Heights presents a plurality of styles. Language in the novel is full of contradictions. The specific tensions and paradoxes built into linguistic patterns are noticeable in the wordstructure and sentence -structure which lend complexity and richness to the text. What is remarkable in Brontë's lexicon is the striking use of her verbs. It is full of violent movement and conflict and has momentum and energy as evident even in the speeches of her characters. Words wreck vocal violence and since her characters carry the unmediated emotions of childhood into their adult lives, they are forever bickering; quarrel being the favoured mode of communication. The characters and their environment are presented through appropriate diction. Wuthering Heights is described as a place which experiences 'atmospheric tumult'. Further, even those passages of excessive emotion are controlled stylistically by breaks from past to present tense, interjected remarks, by broken phrases, and half-expressed ideas which reveal the psychological state of her characters. In addition the sparse but vivid description gives the text a highly emotive texture. Apart from these, her powerful imagery also helps to make her work truly idiosyncratic.

\section{Works Cited}

[1] Emily Brontë. Wuthering Heights. 1992. Hertfordshire:Wordsworth, 2000.

[2] David Lodge. Language of Fiction-Essays in Criticism and Verbal Analysis of the English Novel. (1966). London: Routledge and Kegan Paul, 1984.

[3] G. N Leech and Mick Short. Style in Fiction. London: Longman, 1981.

[4] Northrop Frye. "Myth, Fiction and Displacement" (1961) in Literary Criticism: A Reading. (ed.) B. Das and Jitendra Mohanty.

Calcutta: Oxford UP, 1985.

[5] Nicholas Marsh. Emily Brontë - Wuthering Heights. London: Macmillan, 1999.

[6] Steve Davies. Emily Brontë. U.K: Northcote House Publishers Ltd, 1998.

[7] Thomas A. Volger. (ed.) "20th Century Interpretations of Wuthering Heights" in Wuthering Heights : A Collection of Critical Essays. New Jersey: Prentice Hall Inc, 1968. 